\title{
Effect of Nutrient Management and Crop Establishment Methods of Rice on Biological Properties of Soil
}

\author{
Rajesh Kumar Pal ${ }^{1 *}$, Pankaj Singh ${ }^{1}$, A. K. Pant ${ }^{2}$, Sanjay Tiwari ${ }^{1}$, \\ Shivam Maurya ${ }^{3}$ and Sanjay Kumar Singh ${ }^{1}$
}

${ }^{1}$ Department of Soil Science, ${ }^{3}$ Department of Plant Pathology, Dr. Rajendra Prasad Central Agricultural University, Pusa, Bihar, India

${ }^{2}$ Department of Soil Science, Govind Ballabh Pant University of Agriculture and Technology, Pantnagar, Uttarakhand, India

*Corresponding author

\section{Keywords}

Nutrient

Management, DSR,

Transplanting,

MBC,

Vermicompost

Article Info

Accepted:

15 December 2019

Available Online:

20 January 2020

\section{A B S T R A C T}

A field experiment was conducted at Research Farm, Dr. RPCAU Pusa, Bihar during kharif 2018 on calcareous sandy loam soil, having $\mathrm{pH} 8.57$, medium in soil organic carbon content $(0.65 \%)$, EC $0.35 \mathrm{dSm}^{-1}$, available nitrogen $(195 \mathrm{~kg} / \mathrm{ha})$, available phosphorus $(26.63 \mathrm{~kg} / \mathrm{ha})$ and available potassium $(134 \mathrm{~kg} / \mathrm{ha})$. Experiment was laid-out in split-plot designand replicated thrice. Main-plot included three crop establishment methods, viz. dry direct-seeded rice (DSR-dry), wet direct-seeded rice (DSR-wet) and puddled transplanted rice (TR). In sub-plots, five nutrient management methods $\mathrm{T}_{1^{-}} 100 \%$ STCR Based Dose of Fertilizer + $\mathrm{ZnSO}_{4} @ 25 \mathrm{~kg} \mathrm{ha}^{-1}(\mathrm{DF}), \mathrm{T}_{2}-75 \% \mathrm{DF}+25 \%$ STCR based Recommended Dose of Nitrogen (RDN) through Vermicompost, $\mathrm{T}_{3}-100 \%$ STCR based RDN through Vermicompost, $\mathrm{T}_{4^{-}} 100 \% \mathrm{DF}+50 \%$ STCR based RDN through Vermicompost and $\mathrm{T}_{5^{-}}$ $50 \%$ DF $+25 \%$ STCR based RDN throughVermicompost. The post-harvest soil was analysed to evaluate the effect of different nutrient management methods on soil microbial biomass Carbon (SMBC), soil microbial biomass Nitrogen(SMBN), Microbial population and Dehydrogenase Enzyme (DH) activity under the three different establishment methods. The results indicated that fungal and bacterial population was higher in transplanted rice while actinomycetes population was higher in DSR-dry.The microbial population count was highest under $\mathrm{T}_{3}-100 \%$ RDNfollowed by $\mathrm{T}_{4}-100 \% \mathrm{DF}+50 \%$ RDN.The DH, MBC and MBN recorded higher values of $28.74 \mu \mathrm{g} \mathrm{TPF} \mathrm{g}^{-1} \mathrm{hr}^{-1}, 292.6 \mathrm{mg}$ $\mathrm{kg}^{-1}$ and $32.20 \mathrm{mg} \mathrm{kg}^{-1}$ respectively under transplanted rice whereas, DSR-dry recorded lower value.The DH, SMBC and SMBN were significantly influenced by the application of $\mathrm{T}_{3}-100 \%$ RDNwhich recorded $33.64 \mu \mathrm{g}$ TPF g ${ }^{-1} \mathrm{hr}^{-1}, 317.1 \mathrm{mg} \mathrm{kg}^{-1} \& 33.27 \mathrm{mg} \mathrm{kg}$ ${ }^{1}$ respectively while significantly lower value was recorded with $\mathrm{T}_{1}-100 \%$ DF20.12 $\mu \mathrm{g}$ TPF $\mathrm{g}^{1} \mathrm{hr}^{-1}, 249.1 \mathrm{mg} \mathrm{kg}^{-1}$ and $27.36 \mathrm{mg} \mathrm{kg}^{-1}$ respectively. Therefore it may be concluded that addition of organics (vermicompost) led to improvement of microbial as well as enzymatic activity which was more pronounced in DSR-wet and Transplanted rice. 


\section{Introduction}

Use of high energy agricultural inputs like fertilizers and pesticides cause environmental hazards, so it is desirable to develop a sustainable production system that give optimum productivity with minimum environmental pollution (Singh et al., 2010). Microbes harbouring rhizosphere of crops provide benefits to crops through better nutrient availability by way of atmospheric N2 fixation or solubilizing fixed mineral forms of nutrients (Pandey et al., 2010). Use of integrated nutrient management yields maximum counts and establishment of microbes in soil rather than sole application of chemical fertilizer treatments (Kumar et al., 2014).

Vermicompost is a product derived from the accelerated biological degradation of organic wastes by earthworms and microorganisms. It is a low cost technology, environmentfriendly process used to treat organic waste. The process accelerates the rates of decomposition of the organic matter, alter the physical and chemical properties of the material, leading to a humification effect in which the unstable organic matter is fully oxidized and stabilized (Orozco et al., 1996). The end product, commonly referred as vermicompost is greatly humified through the fragmentation of the parent organic materials by earthworm and colonization by microorganisms (Edwards and Neuhauser, 1988). During this process, the important plant nutrients in the material (particularly the nitrogen, potassium, phosphorus and calcium) are released and converted through microbial action into forms that are much more soluble and available to plants than those in the parent compounds (Ranganathan, 2006).

Soil microbial biomass provides a measure of the quantity of living microbial biomass present in the soil and accounts for 1-5\% of the total soil organic matter (Smith and Paul, 1990). Soil microbial biomass acts as a source or sinks of available nutrients, and plays a critical role in nutrient transformation in terrestrial ecosystems (Singh et al., 1989). Change in the microbial biomass affects soil organic matter turnover and soil microbial activity which has a direct influence on ecosystem stability and fertility. Use of reduced tillage, residue retention and INM recycling $\mathrm{C} \& \mathrm{~N}$ leading to higher microbial biomass $\mathrm{C}, \mathrm{N}$ and dehydrogenase activity (Yadav et al., 2017).

It is a well-known fact that more biologically active soils are characterized by higher microbial biomass leading to enhanced soil enzyme activities and soil respiration (Doran et al., 1996). Hence, maintenance of soil fertility is essential to improve and sustain crop yield and soil organic carbon (SOC) (Stark et al., 2007). However, organic amendments affect soil biological processes by effecting microbial functioning, composition, and population (Marschner et al., 2003). Organic manure increases soil microbial biomass (Peacock et al., 2001), and enzyme activities along with SOC and concentration of other nutrients such as nitrogen (Crecchio et al., 2001).

Soil enzymes allow microbes to access energy and nutrients present in complex substances through nutrient mineralization and humification processes (Allison and Vitousek, 2005). The dehydrogenase depicts the direct oxidative capability of viable microorganisms present in the soil and is indicative for microbial activities (Trevors, 1984).

\section{Materials and Methods}

The field experiment was carried out during Kharif seasons in 2017-18 at Research Farm, Dr. Rajendra Prasad Central Agricultural University, situated in Samastipur district of 
Bihar at an altitude of $52.0 \mathrm{~m}$ and between $25.98^{0} \mathrm{~N}$ latitude and $85.67^{\circ} \mathrm{E}$ longitudes. The soil of experimental field was calcareous sandy loam in texture class $(56.84 \%$ Sand, $31.35 \%$ silt and $11.79 \%$ clay) and alkaline in reaction $(\mathrm{pH} 8.57)$. It was moderately fertile, medium in soil organic carbon content $(0.65$ $\%$ ), electrical conductivity (EC) $0.35 \mathrm{dSm}^{-1}$, low in available nitrogen (195 kg/ha), medium to high in available phosphorus $(26.63 \mathrm{~kg} / \mathrm{ha})$ and medium in available potassium $(134 \mathrm{~kg} / \mathrm{ha})$.

The experiment was laid-out in a split-plot design (SPD). The main-plot treatments included three crop establishment methods, viz. puddle transplanted rice $\left(\mathrm{M}_{1}-\mathrm{TPR}\right)$, wet direct-seeded rice $\left(\mathrm{M}_{2}\right.$-DSR-wet) dry direct seeded rice $\left(\mathrm{M}_{3}\right.$-DSR-dry). In sub-plots, five different nutrient management methods were $\mathrm{T}_{1}(100 \%$ STCR Based Dose of Fertilizer + $\left.\mathrm{ZnSO}_{4} @ 25 \mathrm{~kg} \mathrm{ha}{ }^{-1}\right), \mathrm{T}_{2}(75 \% \mathrm{DF}+25 \%$ STCR based Recommended Dose of Nitrogen through Vermicompost), $\mathrm{T}_{3} \quad(100 \% \quad \mathrm{STCR}$ based Recommended Dose of Nitrogen through Vermicompost), $\mathrm{T}_{4}(100 \% \mathrm{DF}+50 \%$ STCR based Recommended Dose of Nitrogen through Vermicompost) and $\mathrm{T}_{5}(50 \% \mathrm{DF}+$ 25\% STCR based Recommended Dose of Nitrogen through Vermicompost) were replicated thrice under each method. The soil samples collected from rhizosphere of rice at post harvesting stage were analysed for microbial population by Plate count method using serial dilution (SubbaRao, 1988), SMBC by Jenkinson and Ladd, 1981, SMBN by Brooks et al., 1985 and DH by Casida et al., 1964.

\section{Results and Discussion}

Microbial population (Table-1) of soil after harvest of rice was significantly influenced due to different establishment methods and nutrient management. The maximum number of fungi population was recorded under $\mathrm{M}_{1}$ -
Transplanted rice (30.63 $\mathrm{cfu} \mathrm{g}^{-1}$ ) which was significantly higher over DSR treatments. Among the sub-plot treatments fungal population followed the order $M_{1}>M_{2}>M_{3}$. The maximum population of fungi was observed under $\mathrm{T}_{3}-100 \%$ RDN (33.30 $\mathrm{cfu} \mathrm{g}^{-1}$ ) and $\mathrm{T}_{4}-100 \% \mathrm{DF}+50 \% \mathrm{RDN}\left(33.30 \mathrm{cfu} \mathrm{g}^{-1}\right)$ and minimum population of fungi was found under $\mathrm{T}_{1}-100 \%$ DF (22.91 cfu $\left.\mathrm{g}^{-1}\right)$ was significantly lower. The fungal population recorded an increase of 4.10 to $45.38 \%$ under organic amended treatments as compared inorganic alone. This might be due to acidic environment created by the application of oganics (Fig. 1). The maximum actinomycetes population was recorded under $\mathrm{M}_{3}$-DSR-dry (63.27 cfu $\left.\mathrm{g}^{-1}\right)$ which was significantly superior to $\mathrm{M}_{1}$-Transplanted rice (60.01 $\mathrm{cfu} \mathrm{g}^{-1}$ ) and $\mathrm{M}_{2}$-DSR-wet (55.34 cfu g $\left.{ }^{1}\right)$ was at par with $M_{1}$-Transplanted rice. Among nutrient management systems, maximum population of actinomycetes were found under $\mathrm{T}_{3}-100 \% \mathrm{RDN}$ (70.49 $\mathrm{cfu} \mathrm{g}^{-1}$ ) which was significantly superior to rest of the treatments and minimum actinomycetes population was recorded under $\mathrm{T}_{1}-100 \% \mathrm{DF}$ $\left(49.16 \mathrm{cfu} \mathrm{g}^{-1}\right)$. The percentage increase in the population of actinomycetes recorded an increase of 8.90 to $43.38 \%$ under organic amended treatments as compared to chemical alone (Fig.-1). The maximum population of bacteria was found under $\mathrm{M}_{1}$-Transplanted rice (49.60 $\mathrm{cfu} \mathrm{g}^{-1}$ ) which was significantly superior to $\mathrm{M}_{3}$-DSR-dry $\left(43.38 \mathrm{cfu} \mathrm{g}^{-1}\right)$ and at par with $\mathrm{M}_{2}$-DSR-wet (46.44 $\mathrm{cfu} \mathrm{g}^{-1}$ ) was at par with $\mathrm{M}_{1}$-Transplanted rice. Among treatments the maximum population of bacteria was found under $\mathrm{T}_{3}-100 \%$ RDN $\left(54.54 \mathrm{cfu} \mathrm{g}^{-1}\right)$ followed by $\mathrm{T}_{4}-100 \% \mathrm{DF}+$ $50 \%$ RDN (51.47 $\mathrm{cfu} \mathrm{g}^{-1}$ ) which was at par with it and minimum population of bacteria was found under $\mathrm{T}_{1}-100 \% \mathrm{DF}$ (39.32 $\mathrm{cfu} \mathrm{g}^{-1}$ ). The bacterial population (Fig.-1) under organic treatments recorded an increase of 6.89 to $38.70 \%$ over inorganic treatments (RDF). In case of different establishment 
methods of rice crop, higher bacterial and fungi population were found under $\mathrm{M}_{1}$ Transplated rice might be due to more quantity of organic matter available for microbial population but higher actinomycetes population was observed under $\mathrm{M}_{3}$-DSR-dry. Actinomycetes preferred in slight alkaline $\mathrm{pH}$ and dry conditions compare to wet. Kumar et al. 2015 also reported similar results. The overall increase in microbial population was more under $\mathrm{T}_{3^{-}}$ $100 \% \mathrm{RDN}$ and $\mathrm{T}_{4}-100 \% \mathrm{DF}+50 \% \mathrm{RDN}$ having organic alone and in combination respectively. This might be due to the congenial soil atmosphere provided by the integrated approach which would sustain the fertility for long period. The results are in agreement with other studies on long-term experiments that have shown effects on microbial biomass and activity and also shift in microbial community after addition of organic amendments Marschner et al., (2003); Bohme et al., (2005). Venkateswarlu and Srinivasarao, (2004) reported that both the microbial population as well as its diversity index increased in presence of FYM than inorganic fertilization and control. This may be related in our study to higher load of heterotrophic bacterial, fungal, actinobacterial, and denitrifying bacterial populations in vermicompost amended soil followed by INM. Similar result was found by Preethi et al., (2013).

The highest dehydrogenase enzyme activity was recorded under $\mathrm{M}_{1}$-Transplanted rice (28.74 $\mu \mathrm{g}$ TPF $\mathrm{g}^{-1} \mathrm{hr}^{-1}$ ) followed by $\mathrm{M}_{2}$-DSRwet $\left(27.17 \mu \mathrm{g}\right.$ TPF $\left.\mathrm{g}^{-1} \mathrm{hr}^{-1}\right)$ which was at par with it and significantly superior to $\mathrm{M}_{3}$-DSRdry $\left(25.16 \mu \mathrm{g} \quad\right.$ TPF $\left.\quad \mathrm{g}^{-1} \mathrm{hr}^{-1}\right)$. The Dehydrogenase activity is generally used as an indicator of biological activity in soil as this enzyme is known to oxidize soil organic matter. The Dehydrogenase activity was found highest under transplanted rice shows that the soil in the treatment had more potential to support biochemical processes which are essential for maintaining fertility as well as soil health. Similar result was reported by Kumar et al., (2015). Nutrient management systems indicated significant effect on dehydrogenase enzyme activity, the highest dehydrogenase enzyme activity was found under $\mathrm{T}_{3}-100 \% \mathrm{RDN}\left(33.64 \mu \mathrm{g} \mathrm{TPF}^{-1}\right.$ $\mathrm{hr}^{-1}$ ) followed by $\mathrm{T}_{4}-100 \% \mathrm{DF}+50 \% \mathrm{RDN}$ (31.20 $\mu \mathrm{g}$ TPF $\mathrm{g}^{-1} \mathrm{hr}^{-1}$ ) which was at par with it and lowest dehydrogenase enzyme activity was found under $\mathrm{T}_{1}-100 \% \mathrm{DF}(20.12 \mu \mathrm{g} \mathrm{TPF}$ $\left.\mathrm{g}^{-1} \mathrm{hr}^{-1}\right)$. The performance of soil enzymes as biocatalysts of specific reactions as influenced by incorporation of organic amendments to soil added as the material may contain intracellular and extracellular enzymes which encourage microbial activity in the soil (Pascual et al., 1999). The improved soil enzyme and biological activities in our study are believed to be direct indicators of the improvement of soil fertility caused from the incorporation of vermicompost, which helps to increase nutrient availability. Similar result was observed by Preethi et al., (2013).

The maximum $\mathrm{MBC}$ was found under Transplanted Rice (292.6 mg kg-1) followed by DSR-wet (286.8 $\mathrm{mg} \mathrm{kg}^{-1}$ ) and DSR-dry (270.4 $\mathrm{mg} \mathrm{kg}^{-1}$ ). Treatment $\mathrm{T}_{3}-100 \% \mathrm{RDN}$ (317.1 $\mathrm{mg} \mathrm{kg}^{-1}$ ) recorded maximum MBC which was significantly superior to rest treatments and least MBC was recorded under $\mathrm{T}_{1}-100 \% \mathrm{DF}$ (249.1 $\left.\mathrm{mg} \mathrm{kg}^{-1}\right)$. The highest soil microbial biomass nitrogen was recorded in $\mathrm{M}_{1}$-Transplanted rice $\left(32.20 \quad \mathrm{mg}^{\mathrm{kg}} \mathrm{kg}^{-1}\right)$ followed by $\mathrm{M}_{2}$-DSR-wet (30.31 $\mathrm{mg} \mathrm{kg}^{-1}$ ) which was at par with it and $\mathrm{M}_{3}$-DSR-dry (28.18 $\mathrm{mg} \mathrm{kg}^{-1}$ ) was significantly lower. The highest soil microbial biomass nitrogen was found under $\mathrm{T}_{3}-100 \% \mathrm{RDN}\left(33.27 \mathrm{mg} \mathrm{kg}^{-1}\right.$ ) followed by $\mathrm{T}_{4}-100 \% \mathrm{DF}+50 \% \mathrm{RDN}(32.18$ $\mathrm{mg} \mathrm{kg}{ }^{-1}$ ) which was at par with it. The least soil microbial biomass nitrogen was recorded under treatment $\mathrm{T}_{1}-100 \% \mathrm{DF}\left(27.36 \mathrm{mg} \mathrm{kg}^{-1}\right)$ which was at par with it $\mathrm{T}_{5}-50 \% \mathrm{DF}+25 \%$ RDN (28.37 $\left.\mathrm{mg} \mathrm{kg}^{-1}\right)$. 
Table.1 Effect of nutrient management and crop establishment methods on soil microbiological properties at post-harvest of rice

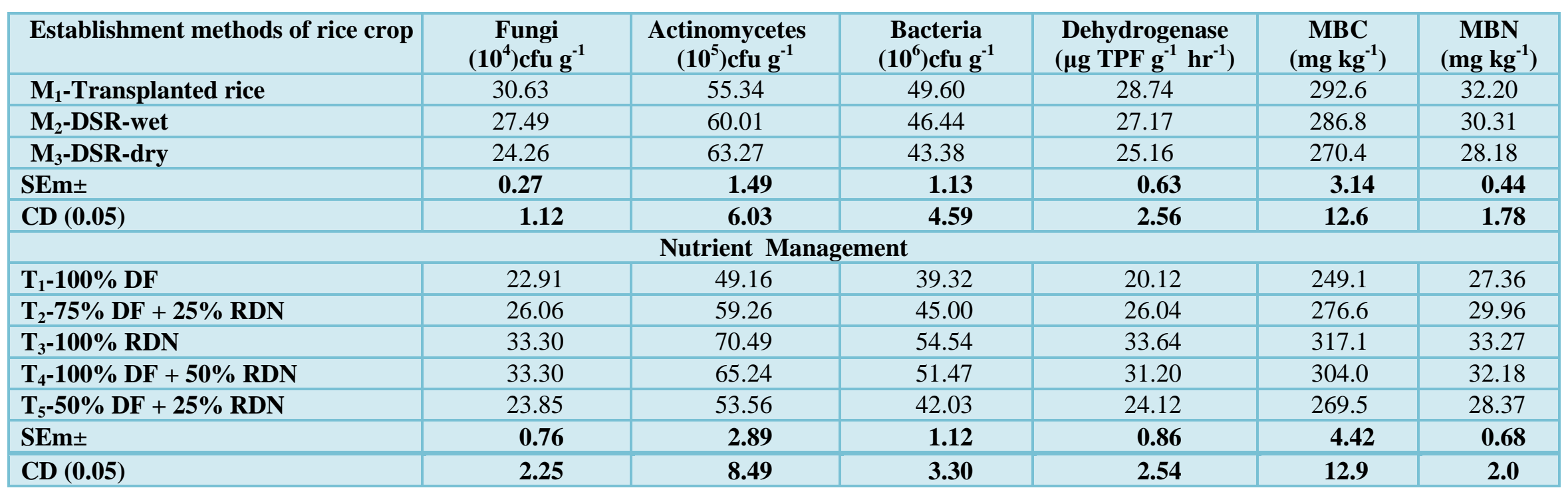

Table.2 Grain, Straw yield $\left(\mathrm{q} \mathrm{ha}^{-1}\right)$ \& Nitrogen uptake of rice as influenced by different nutrient management system and crop establishment methods

\begin{tabular}{|c|c|c|}
\hline Establishment methods of rice crop & Grain Yield $\left(\mathrm{q} \mathrm{ha}^{-1}\right)$ & Straw Yield $\left(q\right.$ ha $\left.^{-1}\right)$ \\
\hline$M_{1}$-Transplanted rice & 51.0 & 60.8 \\
\hline$M_{3}$-DSR-dry & 46.2 & 56.3 \\
\hline CD (0.05) & 1.71 & 2.38 \\
\hline \multicolumn{3}{|c|}{ Nutrient Management } \\
\hline $\mathrm{T}_{1}-100 \% \mathrm{DF}$ & 48.9 & 58.3 \\
\hline $\mathrm{T}_{4}-100 \% \mathrm{DF}+50 \% \mathrm{RDN}$ & 52.1 & 62.7 \\
\hline $\mathrm{T}_{5}-50 \% \mathrm{DF}+25 \% \mathrm{RDN}$ & 44.9 & 54.5 \\
\hline SEm \pm & 1.28 & 1.21 \\
\hline CD (0.05) & 3.76 & 3.56 \\
\hline
\end{tabular}


Fig.1 Percent increase in microbial population of organic treatments as compared to RDF treatments $\left(\mathrm{T}_{1}\right)$ at harvest rice

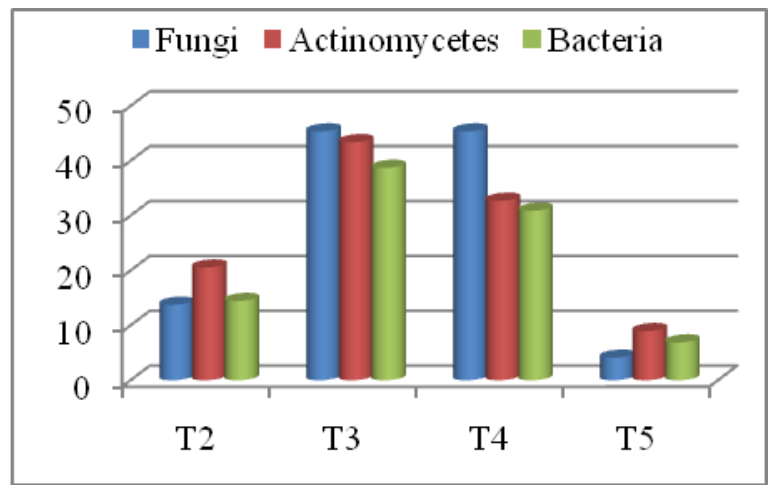

Fig.2 Percent increase in soil biological properties of organic treatments as compared to RDF treatments $\left(\mathrm{T}_{1}\right)$ at harvest rice

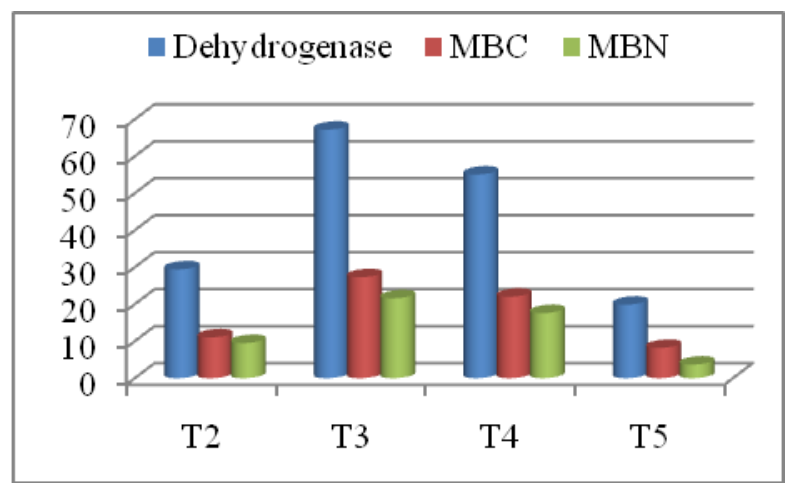

The dehydrogenase, MBC \& MBN (Fig.-2) also recorded an increase ranging from 19.88 to $67.19 \%$ in dehydrogenase activity, 8.10 to $27.29 \%$ in $\mathrm{MBC}$ and 3.60 to $21.60 \%$ in MBN under organically amended treatments $\left(\left(75 \% \mathrm{DF}+25 \% \mathrm{RDN}, \mathrm{T}_{3}-100 \% \mathrm{RDN}, \mathrm{T}_{4}{ }^{-}\right.\right.$ $100 \% \mathrm{DF}+50 \% \mathrm{RDN} \& \mathrm{~T}_{5}-50 \% \mathrm{DF}+25 \%$ $\mathrm{RDN})$ as compared to inorganic alone $\left(\mathrm{T}_{1^{-}}\right.$ $100 \%$ DF).In general, different organic amendments along with inorganic NPK showed good MBC than inorganic application and control. This increase in soil MBC can be ascribed to the incorporation of simply degradable materials, which encouraged microbial activity (Tejada et al. 2006). The readily metabolizable $\mathrm{C}$ and $\mathrm{N}$ in organic manure in addition to increasing root biomass and root exudates leads to better crop growth which is most influential factor contributing to microbial biomass increase. Similar results have also been reported by several other workers Kaur et al., (2005) and Preethi et al., (2013).

\section{Grain and straw yield}

The transplanted method of establishment and $\mathrm{T}_{4}-100 \% \mathrm{DF}+50 \% \mathrm{RDN}$ recorded significantly higher grain and straw yield (Table- 2) of rice which was followed by DSR-wet and $\mathrm{T}_{2}-75 \% \mathrm{DF}+25 \% \mathrm{RDN}$ under method of establishment and nutrient management respectively. The higher grain yield was recorded under transplanted rice due to availability of more nutrients, light, space and moisture as puddling also restrict 
percolation losses. Higher grain yield under transplanting method were also reported by Mallareddy and Padmaja, (2013), Jaiswal and Singh, (2001) and Kumar et al., (2018). In case of nutrient management higher grain and straw yield under $\mathrm{T}_{4}-100 \% \mathrm{DF}+50 \% \mathrm{RDN}$ and $\mathrm{T}_{2}-75 \% \mathrm{DF}+25 \%$ RDNmight be due to improvement in nutrient supply with more organics, which improved the soil physicochemical and biological properties as evident from the results obtained (Tab.1 ; Fig. $1 \& 2$ ). The improved biological properties provided congenial atmosphere and essential food for microbes ultimately leading to enhanced fertility and better yield.

Therefore, it may be concluded from the present study that the micro environment of the soil was better under transplanted and DSR-wet rice which had more number of microbes as well as improved enzymatic activity. Similar the use of organics alone or in combination enhanced the microbial and enzymatic activity leading to higher yields.

\section{References}

Allison, S. D. and Vitousek, P. M. (2005).Responses of extracellular enzymes to simple and complex nutrient inputs.Soil Biology and Biochemistry, 37(5): 937-944.

Bohme, L., Langer, U., Bohme, F. (2005). Microbial biomass, enzyme activities and microbial community structure in two European long-term field experiments. Agriculture, Ecosystems and Environment, 109(1-2): 141-152.

Brookes, P.C., Landman, A., Pruden, G. and Jenkinson, D.S. (1985). Chloroform fumigation and the release of soil nitrogen: a rapid direct extraction method to measure microbial biomass nitrogen in soil. Soil Biology and Biochemistry, 17: 837-842.

Casida, L.E., Klein, D., Santoro, T.,
(1964).Soil dehydrogenase activity.Soil Science.98: 371-376.

Crecchio, C., Curci, M., Mininni, R., Ricciuti, P. and Ruggiero, P. (2001).Short term effects of municipal solid waste compost amendments on soil carbon and nitrogen content, some enzyme activities and genetic diversity.Biology and Fertility of Soils, 34(5): 311-318.

Doran, J. W., Sarrantonio, M., Liebig, M. A. (1996).Soil health and sustainability.Advances in Agronomy, 56: $1-54$.

Edwards, C.A. and Neuhauser, E.F. (1988).Earthworms in Waste and Environmental Management.SPB Acad. Publ., The Hague, The Netherlands.

Jaiswal, V. P. and Singh, G. R. (2001).Effect of planting methods, source and level of nitrogen on the growth and yield of rice (OryzasativaL.) and on succeeding wheat (TriticumaestivumL.).Indian Journal of Agronomy 46(1): 5-11.

Jenkinson, D. S. and Ladd, J. N. (1981). Microbial biomass in soil: measurement and turnover in Soil. Journal of Plant Nutrition and Soil Science, 166: 232238

Kaur, K., Kapoor, K. K., Gupta, A. P. (2005). Impact of organic manures with and without mineral fertilizers on soil chemical and biological properties under tropical conditions.Journal of Plant Nutrition and Soil Science, 168(1): 117-122.

Kumar, A., Kumar, P., Gera, R., Kumar, M. and Ishmadhu. 2014. Effect of integrated nutrient management on crop yield, available nutrient status and microbial status of soil in pearl milletwheat cropping system. Crop Res., 48(1,2\&3): 22-26.

Kumar, K. A., Swaina, D. K. and Bhadoria, P. B. S. (2018). Split application of organic nutrient improved productivity, nutrition al quality and economics of 
rice-chickpea cropping system in lateritic soil, Field Crops Research,223: 125-136.

Kumar, R., Singh, R. N., Sengar, S. S. and Singh, A. K. (2015).Influence of crop residues under rice planting and nutrient management on soil microbial dynamics and productivity of chickpea in vertisols. The Ecoscan, 8: 299-304.

Mallareddy, M. and Padmaja, B. (2013).Response of rice (Oryzasativa) varieties to nitrogen under aerobic and flooded conditions.Indian Journal of Agronomy, 58(4): 500-555.

Marschner, P., Kandeler, E., Marschner, B., Patra, A. K. (2003). Structure and function of the soil microbial community in a long-term fertilizer experiment. Soil Biology and Biochemistry, 35(3): 453-461.

Orozco, S. H., Cegarra, J., Trujillo, L. M. and Roig, A. (1996) Vermi composting of coffee pulp using the earthworm (Eiseniafoetida) effects on $\mathrm{C}$ and $\mathrm{N}$ contents and the availability of nutrients. Biology and Fertility of Soils, 22: 162-166.

Pandey M. P., Verulkar S. B. and Sharma D. (2010). Rice research: past achievements, present scenario and future thrust. Indian Journal of Agricultural Sciences.80(6):447-469.

Pascual, J. A., García, C., Hernández, T. (1999).Comparison of fresh and composted organic waste in their efficacy for the improvement of arid soil quality.Bioresource Technology, 68(3): 255-265.

Peacock, A. D., Mullen, M. D., Ringelberg, D. B., Tyler, D. D., Hedrick, D. B, Gale, P. M. and White, D. C. (2001). Soil microbial community responses to dairy manure or ammonium nitrate applications.Soil Biology and Biochemistry, 33(7-8): 1011-1019.

Preethi, B., Poorniammal, R., Balachandar,
D., Karthikeyan, S., Chendrayan, K., Bhattacharyya, P., and Adhya, T. K. (2013).Long-term organic nutrient managements foster the biological properties and carbon sequestering capability of a wetland rice soil. Archives of Agronomy and Soil Science, 59(12): 1607-1624.

Ranganathan, L. S. (2006). VermibiotechnologyFrom Soil Health to Human Health. Agrobios (INDIA), Jodhpur.

Singh, J. S., Raghubanshi, A. S., Singh, R. S. and Srivastava, S. C. (1989). Microbial biomass acts as a source of plant nutrients in dry tropical forest and savanna. Nature.338: 499-500.

Singh, Y.V., Singh, K.K., Sharma, S.K. and Meena, D.S. 2010. Effect of integrated nutrient management on yield and seed quality in rice.Oryza, 47(3): 215-220.

Smith, J. L. and Paul, E. A. (1990). The significance of soil microbial biomass estimations. In Bollag JM, Stotzky G (eds). Soil Biochemistry. New York: Marcel Dekker Inc., 3: 57-96.

Stark, C., Condron, L. M., Stewart, A., Di. H. J. and O'Callaghan, M. (2007). Influence of organic and mineral amendments on microbial soil properties and processes. Applied Soil Ecology,35(1): 79-93.

SubbaRao, N.S. 1988. Biological Nitrogen Fixation.Oxford and IBH Pub. Co., New Delhi.

Tejada M, Hernandez MT, Garcia C. 2006. Application of two organic amendments on soil restoration: effects on the soil biological properties. Journal of Environmental Quality,35(4):10101017.

Trevors, J. T. (1984). Dehydrogenase activity in soil.A comparison between the INT and TTC assay.Soil Biology and Biochemistry, 16(6): 673-674.

Venkateswarlu, B. and Srinivasarao, C. 
(2004).Soil microbial diversity and the impact of agricultural practices.Indian Journal of Dry land Agricultural Research and Development,19(2): 97105.

Yadav, G. S., Lal, R., Meenab, R. S., Babu, S., Das, A., Bhowmika, S. N., Dattaa,
M., Layak, J. and Sahaa, P. (2017). Conservation tillage and nutrient management effects on productivity and soil carbon sequestration under double cropping of rice in north eastern region of India. Ecological Indicators.

\section{How to cite this article:}

Rajesh Kumar Pal, Pankaj Singh, A. K. Pant, Sanjay Tiwari, Shivam Maurya and Sanjay Kumar Singh. 2020. Effect of Nutrient Management and Crop Establishment Methods of Rice on Biological Properties of Soil. Int.J.Curr.Microbiol.App.Sci. 9(01): 1943-1951. doi: https://doi.org/10.20546/ijcmas.2020.901.218 